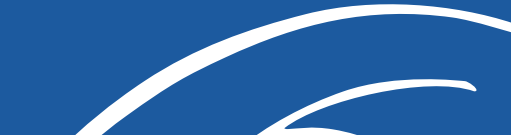 $\curvearrowright$ AGUA water and landscape YTERRITORIO
}

\section{La cartografía hidráulica en Mendoza, Argentina (siglos XVIII y XIX) como herramienta para historiar el espacio y espacializar la historia}

\author{
Hydraulic Mapping in Mendoza, Argentina (18th and 19th centuries) \\ as a Tool for Historizing Space and Spatializing History
}

Jorge Ricardo Ponte

CONICET. Mendoza, Argentina. jorgericardoponte@gmail.com

Resumen - En la historiografía tradicional, la documentación gráfica, como planos históricos y mapas, ha solido usarse con la idea de ilustrar, con la intención de amenizar un texto, como podía hacerse con una fotografía o un grabado antiguo. Se desperdiciaba así la posibilidad de considerar a estos documentos gráficos como una fuente de información histórica en sí misma. Estos planos de proyectos de servicios (cloacales, de aguas corrientes, pavimentos, etc.) suelen contener no sólo delimitado el espacio histórico, sino que lo complementan con la inserción de información literal, representaciones iconográficas 0 arquitectónicas, antiguos o nuevos cursos de agua, curvas de nivel, localización del equipamiento público, tipos de cultivos, instalaciones proto industriales, referencias literarias del equipamiento social, etc. Por ello, el objetivo de este artículo es mostrar las posibilidades que se abren en la investigación histórica mediante la utilización, de manera creativa, de una fuente tradicional como puede ser la cartografía histórica.

El método elegido por nosotros para mostrar la utilidad y potencialidad de planos y mapas antiguos es tomar un plano testigo de 1754, inserto en un litigio por el cierre de una calle que pasaba por un molino en la ciudad de Mendoza a mediados del siglo XVIII y comenzar a construir información histórica, social y catastral sobre él. Procesarlo mediante programas gráficos - que no es lo mismo que hacer geo-referenciación- mostrando las diferentes etapas que implica un proceso de digitalización para, finalmente, contextualizar este plano "re trabajado" en el proceso histórico y político en el cual se inserta. El resultado obtenido de este proceso de digitalización y graficación fue la incorporación al corpus cartográfico mendocino de un plano histórico que se desconocía. Paradójicamente, este plano de 1754 resultó ser el primero de la ciudad de Mendoza real luego del plano ideal de la fundación en 1561. Una de las aportaciones más originales de este proceso de digitalización es la obtención de una imagen del parcelamiento catastral de una banda urbana pericentral al casco fundacional, ya que no existe otro catastro anterior y el próximo, y primer catastro urbano, recién aparecerá en 1885. Una primera conclusión que surge es que, lejos de lo que suele pensarse, el "damero español" no tuvo un mecánico traspaso en el territorio de las ciudades americanas fundadas durante el proceso colonizador español.

Abstract - In traditional historiography, visual documentation, such as historic drawings and maps, has too often being used to illustrate, and thus to enhance, texts with the addition of photos or old engravings. The possibility of considering the historical value of such graphic documents had been usually ignored. Diagrammatic representations of public works projects (such as sewage or running water systems, pavements, etc.) usually contain not only a confined historical space, but also complement it with the inclusion of literal information, iconographic or architectural images, old and new waterways, contour lines, public facility locations, crop types, protoindustrial installations and literary references to social amenities of the featured spaces. Therefore, the aim of this paper is to show the possibilities open to historical research through the creative utilization, via historical cartography, of a traditional source.

The method chosen to show the usefulness and historical potential of old maps and cartograms is to examine a 1754 survey, embedded in a dispute over the closure of a road passing through a mill in the Argentinean city of Mendoza in the middle of the 18th century, and begin weaving historical, social and cadastral information around it. Next, we analyze the map using graphic software (not geo-referencing) to show the different digitization stages involved before finally contextualizing the historical and political processes in which the "reworked" chart had been inserted. The findings of the digitization and computer graphics exploration make available a previously unknown historical plan to the existing cartographic maps of Mendoza. Paradoxically, the 1754 plan turned out to be the first of the real surveys of the city of Mendoza after its founding in 1561. One of the most important contributions of this digitization process is to provide an image of the urban parcels surrounding the historical area where the city had been originally erected. There are no previous images of this zone and the next available survey was completed in 1885. One of our early conclusions is that far from what is usually assumed the "Spanish checkerboard" approach to urban development did not automatically transfer to the territories of American cities founded during the Spanish colonization process.

Palabras clave: planos hidráulicos; espacio; historia; ciudad; digitalización Keywords: Hidraulics projects; space; history; city; digitization

Información Artículo: Recibido: 17 abril 2014

Revisado: 11 junio 2014

Aceptado: 28 julio 2014

(c) Universidad de Jaén / Seminario Permanente Agua, Territorio y Medio Ambiente (CSIC) 